\title{
Evolution of Organizational Power
}

\author{
Jolanta Bieńkowska \\ University of Lodz, Lodz, Poland
}

\begin{abstract}
The surrounding reality undergoes dynamic transformation, which has a substantial impact on the functioning of the organization. One of its important aspects is the organizational authority and forms of its exercise. Therefore, the research problem, undertaken in the article, boils down to the question: what is the direction of changes in the way of organizational governance from birth of management science to the present day? In order to find the answer, the deductive method was used. In contrast, the analysis of the research problem was carried out by adopting two dimensions of power. In the first dimension, the power is treated as a social influence exerted on members of the organization, in the second - as the scope of control over the relationship with the organization's close stakeholders (customers, suppliers, and competitors). Their distinction was emphasized in the structure of the article, firstly in separate parts by presenting the chronology of the occurred changes, then by building up the justification separately for each of them of a pragmatic approach to governance of the organization at the present time. Changing of the dominant character of workers from low-skilled workers into knowledge workers triggered a need to redefine the attitudes of superiors towards seeing the workers in the category of capital necessary for the development of the organization. In turn, the direction of evolution of relations with the environment has been determined by the disappearance of borders between the organization and the environment, which resulted in the need for openness with regards to entering into temporary (instead of the previously long-term) inter-organizational forms of cooperation, thus in the change in tactics of making impact on the stakeholders of the organization. The article's considerations lead to the conclusion that the evolution of organizational authority moves towards its progressive dispersion and the associated autonomy of organizational behaviour. The growing independence of employees and limited opportunities to maintain control over the close environment are forcing organizations to accept uncertainty and the temporariness of measures taken, and to redefine the essence, scope, and modalities for organizational governance. Moreover, they lead to being guided by pragmatic values such as trust and credibility. This situation also leads to the conclusion that the research into developments in the field of organizational governance is important from the point of view of the need to adapt to new and complex ways of its exercise, to respond to the demands of the situation and the expectations under its influence.
\end{abstract}

Keywords: organizational power, leadership, organizational behaviors, organizational space, market, organizational change

\section{Introduction}

The issue of power is inextricably linked to the organization, as it is constituted by a group of people pursuing an aim together and having sufficient resources for its implementation (Aldrich, 2008). One of the key

Jolanta Bieńkowska, Ph.D., Department of Management, Faculty of Management, University of Lodz, Lodz, Poland.

Correspondence concerning this article should be addressed to Jolanta Bieńkowska, Department of Management, Faculty of Management, University of Lodz, Matejki 22/26, 90-237 Lodz, Poland. 
factors of regulating the efficiency of the organization is the power which can be understood as exercising control over organizational measures (Hatch, 2013). However, over the past half century, the importance of power in management has evolved. Both the way how the power is exercised and the force of its impact has changed. The first of these evaluation criteria can refer to the social dimension of power, the process of control of human behavior in organizations (the social space of the organization); the second, to the process of control of the relationship with the environment, on which depends largely the condition of the organization (the market organization) (Sikorski \& Bieńkowska, 2012). The whole gives a complete picture of occurred changes. The purpose of this article is to show their direction and impact on the functioning of the organization.

\section{Literature Review}

In the social dimension of organizational authority, a constant trend has been present since the third decade of the 20th century, setting the direction of evolution that defines the organization as a social system (Roethlisberger \& Dixon, 1939; Parsons, 1961). Although on the timeline, the earlier positions are occupied, among others, by the works of Follett (1924) and Mayo (1933), the milestone became the theories of psychologists, Maslow $(1943 ; 1954)$ and McGregor (1960), who initiated the process of humanization of work, and management ideas propagated by Drucker $(1946 ; 1954 ; 1964)$. The progressive change in the approach to the role of man in the organization was and still is largely the consequence adopted by their assumptions about the nature of man and effective way to motivate him to work. Thus they began to distinguish between management functions of leadership function assuming that people are a valuable asset for an organization that requires investment and stimulation for self-control and development (Bennis, 1989; Kotter, 1990; Kouzes \& Posner, 1987). This latter finding was the foundation of the next phase of transformation of interpretation of the meaning of social influence in the organization towards empowerment (Blanchard, Carlo, \& Randolph, 1996), self-leadership (Sims \& Manz, 1996) and resonant leadership (Boyatzis \& McKee, 2005). The organizational authority in this sense is identified with a group social process, and no longer with the impact of the individual on the group.

The evolution of power in relations with stakeholders of the organization has a slightly different course, because after several decades of consistent efforts of organizations to retain control of the market by building up consortia based on the diversification strategy, in recent years, there has been a significant breakthrough. A boom of strategic thinking (Kiechel, 2012), recorded after World War II, was based on the objective of conducting market game involving the retention of power over the participants of the inner circle — competitors, customers, and suppliers, but also over the participants of the further circle, such as institutions within his legal and political environment through, inter alia, lobbying. Among the scientific achievements that provide knowledge on how to rule the market, what worth mentioning are those by Chandler (1962), Porter (1979; 1980; 1985), Ansoff (1965), and Mintzberg (1994). However, due to the unexpected economic crisis that started in 2008 , the collapse of the trend can be seen. As a result, the basis for building a competitive advantage became a short-lived relationship with co-operators, characterised by a limited mutual effect of market participants on one another, which, however, allows for quick adaptation (Raynor, 2007; Koźmiński, 2013; Martínez-López, 2013). The ability to manage chaos (Kotler \& Caslione, 2009) has become the basic attribute of an efficient organization, which requires the ability to integrate the ease (autonomy, freedom of action) and stiffness, which manifests itself in undisputed tendency to be guided by the overarching values of the organization, such as quality, trust, and credibility (Petres \& Waterman, 2006). 


\section{Evolution of Power in the Social Space of Organization}

Assessing the way in which social power is exercised in the organization; it can be assumed that it depends on the management methods predominant in the given time and aimed at achieving high efficiency. It is transformed under the influence of changes in the approach to human resources. In the industrial age, a very high work capacity was expected from low-skilled workers.

Organizational power had primarily an economic foundation. It was a model accompanying human endeavors for centuries. It was at disposal of a person with high material status, on which their professional position depended in those times. The task of the person who wields authority was to influence subordinates in a way that effectively led to the realization of the objectives set by the person in power (Buchanan \& Badham, 2008). The potential force of impact on the subordinate staff was high and referring to the classical classification of sources of power, based to a large extent on formal authority and power to punish (Robbins, 1988). Their combination shaped the working conditions in which it was expected to comply fully with the dictates of a superior in order to achieve the best performance.

The situation began to change substantially after World War II, when a growing number of studies by psychologists and sociologists showed that the efficiency of work increases along with leaving the employee's freedom of action. In connection with this, the style exercising power had to change its character. The solutions began to be used in which the employees themselves could define their objectives for implementation of the main goal (Stein, 2010), as well as diversification of leadership style depending on the predisposition of the manager, the employee, and the conditions of the work situation (Tannenbaum \& Schmidt, 1973). The mainstream changes aimed to ensure satisfactory conditions of work (Herzberg, 1987; Maslow, Stephens, \& Hail, 1998) and leave the margin of discretion to workers as regards the tasks carried out by them in order to improve the efficiency of the organization. Thus, the way of exerting influence changed significantly. It was targeted to create positive incentives to encourage involvement in the work.

Further change in the approach to exercising the social power was also influenced by the increasing level of education of society which caused the differences between managers of the organization and subordinates substantially decreased due to the increasing professional qualifications of the workers.

The end of the 20th century saw the onset of a rapid increase in the need for innovation and responding to the challenges of the market, which caused the industry cease to be the main driving force behind the global economy, but it was replaced by knowledge. Organizations began to look for and appreciate the highly skilled experts capable of finding and implementing new solutions. Therefore, more and more organizations began to share the idea that people are the most valuable asset to an organization that requires investments aimed not only to provide free access to various forms of education designed to increase competence, but also to empower employees (Porter, Angle, \& Allen, 2003). In the course of the changes made, the social power in the organization began to undergo further dispersion. More and more specialists considerably supported the effective functioning of the organization which began to receive freedom of decision-making.

The way of work organization changed, too. Organizations began to abandon the rigid hierarchical organizational solutions for the adaptable task and network ones. The specificity of the first lies in the fact that, in the organization, temporary groups are formed, whose purpose is to implement an interim operation. Coordination of their course is entrusted with the person having the optimal competences from the point of view of the specific nature of the activity. At the same time, it is assumed that every employee has a potential 
opportunity to lead the team, which leads to further devolution of power. In addition, the role of the person standing at the head of the group has changed significantly, too. It is not expected from that person in the first place to exert a strong social influence, which is in opposition to the autonomy of action, but most of all to take responsibility for the actions of the team and perform discrete control over its effectiveness (Sikorski, 1999).

Whereas in network organizations, the capability of sharing power with cooperators has become essential. The idea of network organizations involves temporary cooperation with other organizations with subsidiary resources necessary to implement the project. Each entity has its own center of power, which is obliged to share the decision-making (Czakon, 2012). Moreover, in the case of network organizations, social impact has a specific nature, since it is based on trust and credibility. These values are the means of making the impact on cooperators, encouraging them to pursue joint ventures (Bieńkowska \& Sikorski, 2015).

As is apparent from the above description, social authority in the organization has undergone a significant metamorphosis - from efforts to subordinate by means of economic coercion, to appealing to pragmatic values as a stabilizer of partnership cooperation - from full centralization to high deconcentration.

\section{Evolution of Power in the Market Space of the Organization}

Organizational power can also be identified with control over the relationship with close stakeholders of the organization: customers, suppliers, and competitors, who make up the market space of the organization.

During the development and dominance of industry in the economy, the behavior of the representatives of the environment close to the organization was predictable. Customers bought what the market dictated. They were choking on the latest novelties and eager to receive them. The market was insatiable, therefore, the behavior of competitors generally did not jeopardize the status quo of organizations, and suppliers willingly co-operated on the basis of long-term contracts. Thus, organizations had control over their own market space. External conditions for the functioning of the organization were considered to be stable and predictable.

However, the rapid development of the product range, launched in the 30s of the 20th century as an antidote to the Great Depression, changed substantially conditions of the functioning of markets. Customers began to make choices, which meant that competition among firms began to gain momentum. The power of the organization over the market space ceased to be stable. The natural defensive reaction seemed to protect the current position. In dealing with customers, creating consumer's needs became a defensive tactic. Organizations competed in providing innovative products and services, and in persuading about their necessity in everyday life.

In modern days, network structural solutions that allow for the establishment of economically profitable cooperative relations began to serve maintaining control over the relationship with suppliers and cooperators. In addition, to defend the competitive position, new management methods, such as outsourcing, lean management, just-in-time, and total quality management, were employed (Jaki, 2007). Thanks to them, the organization could reduce costs of operation, as well as significantly improve its performance. Analyzing the process of evolution of power at this stage, one can notice the two-fold nature of the process of dispersion of control in the social and market space of the organization. In the first area, organizations consciously began to share power with employees; in the other, strategies were aimed at preserving the ability of the impact on the individual stakeholders. The first served the other. The struggle to maintain control over the market space was fought successfully for decades until the turning point - the global economic crisis, initiated in 2007, which caused a change in the nature of economic phenomena from dynamic to turbulent. The unstable financial situation 
significantly changed the behavior of stakeholders and organizations into more conservative. Customers in defense of their household budgets began to refrain from purchasing products outside the set necessary for existence. The passivity of consumers and the need for caution in the disposal of financial resources possessed by the organizations largely limited the potential to compete with other market participants. Additional barrier to maintain control over customers and competitors also began to be created by a shrinking potential of opportunities to deliver innovative products or services. In contrast, cooperation with cooperators took a short-term character to manage and maintain control over its course and, if necessary, be able to quickly respond to adverse changes by the change of a partner.

Therefore, the control of market space today poses many problems. So far, the organizational power served to keep the stability of operation, the current conditions took away this opportunity. This situation means that organizations are faced with the fact that they are not able to exert a strong influence on the behavior of stakeholders. To be able to adapt to market requirements, they should aim to acquire the ability of operational flexibility, manifested among other things by the ability to capture and use of current opportunities (Trompenaars \& Hampden-Turner, 2002), which is extremely difficult, as it requires the abandonment of existing business models (Mierzejewska \& Rudolf, 2011) and the search for new solutions that do not give such a sense of confidence as those previously verifiable.

One of the solutions to improve the condition of the organization is to initiate the creation of network organizations, which has already been mentioned in the discussion of social power. Their temporary nature allows for maintaining control for the duration of the project, controlled maintaining relations with stakeholders within a specific, possible to plan term.

\section{Pragmatism in the Exercise of Organizational Power}

Based on observations of the functioning of modern organizations and literature studies, it can be concluded that the manner of exercising the organizational authority is now conditioned by pragmatism. Its domain is the practicality, usability of undertaken activities, and contesting the accuracy of the final rules that would strictly define the procedure (Hartman, Sifonis, \& Kador, 2011). Both in the industrial and post-industrial era, the management was based on solid organizational solutions and on striving to seek a "one best way". The market situation as well as expectations of employees allowed for this state of affairs. Currently, the dynamic changes occurring in the market space, the unpredictability of events and hyper-competition meant that in contemporary, organizations become a dominant pragmatic approach to managing the organization, characterized by a constant search and implementation of diverse and sometimes extreme solutions in order to gain and maintain a competitive advantage in the market. Therefore, it becomes necessary to have an attribute of hyper-flexibility understood as the ease of creating new organizational forms which enable the use of the opportunities and avoidance of the risks by adapting activities to the needs of the situation. One of the conditions of this ability is the pragmatism in exercising organizational authority, allowing for the rejection of proven methods of action in favour of hybrid and original procedures.

Pragmatism of using the power in the market space refers to changing the rules governing the modern market play among its participants. Due to the fact that the popular organizational solution is to limit the scope of activities to the implementation of basic tasks, it is therefore necessary to liaise with other organizations. The condition for determining the choice of partner is his image, which is evaluated in terms of credibility, responsibility, and professionalism, i.e., values make up the other superior value that is the confidence 
(Melewar \& Syed-Alwi, 2015). This is particularly true in case of virtual organizations, conducting their business via the Internet. Electronic market characterized by high dynamics of change is particularly sensitive in the area of behaviour quality (Karake-Shalhoub, 2002).

Thus, the effectiveness of making impact on co-operators is conditioned by compliance with specific rules. Such an approach is tantamount to the recently popular concept of corporate social responsibility of the organization that promotes building relationships with all stakeholders in an organization based on the values that have become the guardian of ethical behaviour. Although the practice of many organizations shows that under the guise of Corporate Social Responsibility, only superficial actions are carried out, directed at communities rather than key stakeholders - customers, co-operators, and employees, which are designed to manipulate the message addressed to the environment (Nogolica, 2012). However, this approach is in a situation of dependence on business partners and the necessity of taking care of the customer due to high saturation of the market is short-sighted. Currently, business ethics takes on new meaning. Its weight arises from the need to stand out against competitors. Therefore, due to the fact that the possibility of acquiring a customer by the price or even quality because the high competition is limited, it is the values that are becoming a major tool of influence and regulator of the process of concluding and maintaining business relationships (Karake-Shalhoub, 2002).

In the social space as well as in the market space, practical reasons dominate such values like trust and professionalism. In the area of direct interpersonal relations, their promotion is directly related to permission to make mistakes. Such a standard is essential in today's organizations aimed at building its position through innovation. Only taking bold ventures and checking their usefulness by trial and error allow the development of both employees and organizations. Making an impact through the implementation of these values is identical to the management by the values promoted by Blanchard, O'Connor, and Ballard (2003). Their concept is based on the assumption that employee's motivation can be effectively stimulated through the pursuit of the values of the organization which are also identical to their individual needs. In the same way, pragmatics of governance in the social space comes down to awareness of the need to ensure the conditions necessary to stimulate the potential of employees and involvement in solving current problems of the organization. In relation to knowledge workers, responsiblity for creating innovation, indispensably becomes empowerment. The transfer of power is intended to assurance them the freedom to make decisions in the process of generating creative solutions and highlight the role of workers in the development of the organization (Kinlaw, 1995). It results in redefinition of the concept of power-from the ability to influence others (Griffin, 2012) to the ability to make autonomous decisions (Clegg \& Bailey, 2007).

In conclusion, in the classical concept of power, its exercise comes down to define the expected behaviour of subordinates. The pragmatic approach promotes development of standards of behaviour through example, action, and treating the leaders as a reference point. Pragmatism of organizational governance is based on the formation of a situation conducive to networking of cooperation and providing employees with the conditions that stimulate them into effective, creative work. Consequently, there appears a new picture of the organization, where power is not an attribute of managers, nor it is closed in the individual dimension, but it is a management tool serving to stabilize the operation of an organization on a wide organizational level.

\section{Conlcusions}

In the science of management, there was a long-term conviction of the effectiveness of programming 
organizational behavior, both internal —employees of the organization, and external — their close stakeholders. Its basis lays dynamic development of science, which prompted the belief that further progress will provide control over social (Kozielecki, 1977) and economic processes (Księżyk, 2013). It was also determined by the assumption of linearity of observable phenomena (Perechuda, 2007). However, the progressive development of civilization introduced and highlighted a number of independent variables, which verified the views on the way to exercise and potential force of the organizational power.

In the first place, the manner of social impact began to be reviewed, for several decades trying to maintain control over external relations, until also in this area took place a radical transformation. Interestingly, the progressive reduction of social power served to maintain market power. However, this treatment also did not prevent the loss of control over the behavior of stakeholders, putting the organizations before the need to develop capabilities for flexible operation and effective exploration of new business models congruent to today's turbulent environment.

The evolution of power in the organizational space is progressing towards a significant narrowing of the area and the strength of its impact. Empowerment of workers and the inability to maintain close control over the environment are forcing organizations to accept uncertainty and temporariness of undertaken actions, thus redefining the need for exercising the organizational power.

\section{References}

Aldrich, H. (2008). Organizations and environments. Redwood City: Stanford University Press.

Ansoff, H. I. (1965). Corporate strategy. New York: McGraw-Hill.

Bennis, W. G. (1989). Managing the dream: Leadership in the 21th century. Journal Organizational Change Management, 1 , 6-10.

Bieńkowska, J., \& Sikorski, C. (2015). Kult przedsiębiorczości. Dominacja kultury w przestrzeni organizacyjnej. In K. Jaremczuk (Ed.), Przedsiębiorczość-Perspektywq Zmian (pp. 113-125). Przemyśl: Wyższa Szkoła Prawa i Administracji w Przemyślu.

Blanchard, K., Carlos, J. P., \& Randolph, A. (1996). Empowerment takes more than a minute. San Francisco: Berrett-Koehler.

Blanchard, K., O'Connor, M., \& Ballard, J. (2003). Managing by values. San Francisco: Berrett-Koehler Publishers.

Boyatzis, R. E., \& McKee, A. (2005). Resonant leadership: Renewing yourself and connecting with others through mindfulness, hope, and compassion. Boston: Harvard Business Press.

Buchanan, D., \& Badham, R. (2008). Power, politics, and organizational change: Winning the turf game. London: Sage.

Chandler, A. D. (1962). Strategy and structure: Chapters in the history of the industrial enterprise. Boston: Harvard Business School.

Clegg, S., \& Bailey, J. R. (2007). International encyclopedia of organization studies. London: Sage.

Czakon, W. (2012). Sieci w zarzqdzaniu strategicznym. Warszawa: Wolters Kluwer Business.

Drucker, P. (1946). Concept of the corporation. New York: The John Day Company.

Drucker, P. (1954). The practice of management. New York: Harper \& Row Publishers.

Drucker, P. (1964). Managing for results. New York: Harper \& Row Publishers.

Follett, M. P. (1924). Creative experience. New York: Longmans, Green.

Griffin, R. (2012). Management. Boston: Cengage Learning.

Hartman, A., Sifons, J., \& Kador, K. (2011). E-biznes. Warszawa: K. E. Liber.

Hatch, M. J. (2013). Organization theory: Modern, symbolic and postmodern perspectives. Oxford: Oxford University Press.

Herzberg, F. (1987). One more time: How do you motivate employees? Harvard Business Review, 65, 109-120.

Jaki, A. (2007). Wycena i ksztattowanie wartości przedsiębiorstwa. Warszawa: Wolters Kluwer Business.

Karake-Shalhoub, Z. (2002). Trust and loyalty in electronic commerce: An agency theory perspective. Santa Barbara: Greenwood Publishing Group.

Kiechel, W. (2012). The management century. Harvard Business Review, 90(11), 62-75.

Kinlaw, D. C. (1995). The practice of empowerment: Making the most of human competence. Hampshire: Gower Publishing, Ltd.

Kotler, P., \& Caslione, J. A. (2009). Chaotics: The new normality of turbulence. Retrieved from http://www.chaoticsstrategies.com/about-the-authors/the-new-normality/ 
Kotter, J. P. (1990). A force for change: How leadership differs from management. New York: Free Press.

Kouzes, J., \& Posner, B. Z. (1987). The leadership challenge. New York: John Wiley \& Sons.

Kozielecki, J. (1977). Koncepcje psychologiczne człowieka. Warszawa: Państwowy Instytut Wydawniczy.

Koźmiński, A. K. (2013). Polskie laboratorium zarządzania. Harvard Business Review Polska, 121, 46-57.

Księżyk, M. (2013). Ekonomia Podejście historyczne i prospektywne. Kraków: Oficyna Wydawnicza AFM Krakowskie Towarzystwo Edukacyjne.

Martínez-López, F. J. (2013). Handbook of strategic e-business management. New York: Springer Science \& Business Media.

Maslow, A. (1943). A theory of human motivation. Psychological Review, 50, 370-396.

Maslow, A. (1954). Motivation and personality. New York: Harper.

Maslow, A., Stephens, D. C., \& Heil, G. (1998). Maslow on management. John Wiley \& Sons, Inc.

Mayo, E. (1933). The human problem of industrial civilization. New York: The Mcmillan Company.

McGregor, D. (1960). The human side of enterprise. New York: McGraw-Hill.

Melewar, T. C., \& Syed-Alwi, S. F. (2015). Corporate branding: Areas, arenas and approaches. London: Routledge.

Mierzejewska, B., \& Rudolf, T. (2011). Innowacyjne modele biznesowe. E-mentor, 3(40). Retrieved from http://www.e-mentor.edu.pl/artykul/index/numer/40/id/849

Mintzberg, H. (1994). The rise and fall of strategic planning: Reconceiving the roles for planning, plans, planners. New York: Free Press.

Nogolica, A. (2012). An analysis on the public perception of the tobacco industry's corporate social responsibility (CSR) marketing communications (Master's thesis). Diplomarbeiten Agentur.

Parsons, T. (1961). An outline of the social system. In T. Parsons, E. Shils, K. D. Naegele, and J. R. Pitts (Eds.), Theories of society foundations of modern sociological theory (pp. 30-79). New York: Free Press of Glencoe.

Perechuda, K. (2007). Dyfuzja wiedzy w przedsiębiorstwie sieciowym, wizualizacja i kompozycja. Wrocław: Wydawnictwo akademii ekonomicznej im. Oskara Langego we Wrocławiu.

Petres, T. J., \& Waterman, R. H. (2006). In search of excellence: Lessons from America's best-run companies. New York: Harper Business.

Porter, L. W., Angle, H. L., \& Allen, R. W. (2003). Organizational influence processes. New York: M.E. Sharpe.

Porter, M. (1979). How competitive forces shape strategy. Harvard Business Review, 57(2), 137-145.

Porter, M. (1980). Competitive strategy: Techniques for analyzing industries and competitors. New York: Free Press.

Porter, M. (1985). Competitive advantage: Creating and sustaining superior performance. New York: Free Press.

Raynor, E. R. (2007). The strategy paradox: Why committing to success leads to failure (and what to do about it). New York: Crown Business.

Robbins, S. P. (1988). Behavior. Essentials of organizational. New Jersey: Prentice-Hall.

Roethlisberger, F. J., \& Dixon, W. J. (1939). Management and the worker, an account of a research program conducted by the Western Electric Company, Hawthorne works. Chicago. Cambridge: Harvard University Press.

Sikorski, C. (1999). Zachowania ludzi w organizacji. Warszawa: Wydawnictwo Naukowe PWN.

Sikorski, C., \& Bieńkowska, J. (2012). Przestrzeń organizacyjna a efektywność organizacji. Acta Universitatis Lodziensis Folia Oeconomica, 265, 205-213.

Sims, C. C., \& Manz, H. P. (1996). Company of heroes: Unleashing the power of self-leadership. New York: John Wiley and Sons.

Stein, G. (2010). Managing people and organizations: Peter Drucker's legacy. Bingley: Emerald Group Publishing.

Tannenbaum, R., \& Schmidt, W. H. (1973). How to choose a leadership pattern. Harvard Business Review, 51, 162-175.

Trompenaars, F., \& Hampden-Turner, C. (2012). Riding the waves of culture. Understanding cultural diversity in business. New York: McGraw-Hill Education. 